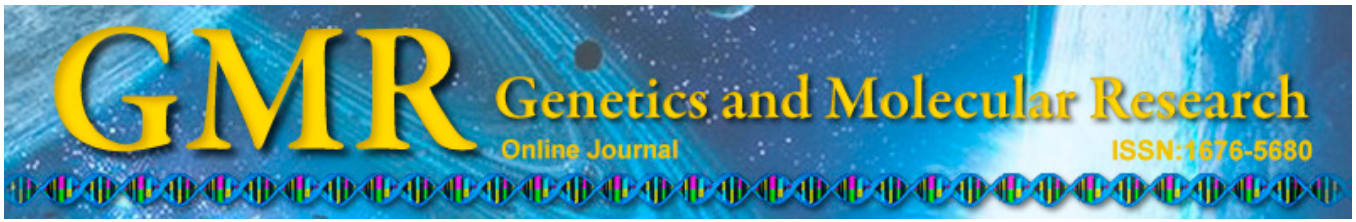

\title{
Genetic control of inflorescence in common bean
}

\author{
S.R. Guilherme ${ }^{1}$, M.A.P. Ramalho ${ }^{1}$, A. de F.B. Abreu ${ }^{2}$ and L.A. Pereira ${ }^{1}$ \\ ${ }^{1}$ Departamento de Biologia, Universidade Federal de Lavras, Lavras, MG, Brasil \\ ${ }^{2}$ Embrapa Arroz e Feijão, Goiânia, GO, Brasil \\ Corresponding author: S.R. Guilherme \\ E-mail: scheila@posgrad.ufla.br
}

Genet. Mol. Res. 13 (4): 10349-10358 (2014)

Received March 26, 2013

Accepted August 8, 2014

Published December 4, 2014

DOI http://dx.doi.org/10.4238/2014.December.4.30

\begin{abstract}
The number of pods per common bean plant is a primary component of grain yield, which depends on the number of flowers produced and on the flower set. Thus, a larger number of flowers per plant would increase yield. Lines with inflorescences that had a large number of flowers compared to common bean plants now under cultivation were identified. We analyzed the genetic control of this trait and its association with grain yield. The cultivar BRSMG Talismã was crossed with 2 lines, L.59583 and L.59692, which have a large number of flowers. The $\mathrm{F}_{1}$, $\mathrm{F}_{2}$, and $\mathrm{F}_{3}$ generations were obtained. These generations were assessed together with the parents in a randomized block experimental design with 2 replications. The traits assessed included length of inflorescence, number of pods per inflorescence, number of pods per plant, number of grains per plant, 100-grain weight, and grain yield per plant. Mean genetic components and variance were estimated. The traits length of inflorescence and number of pods per inflorescence exhibited genetic control with predominance that showed an additive effect. In the 2 crosses, genetic control of grain yield and of its primary components showed that the allelic interaction of dominance was high. The wide variability in the traits assessed may be used to increase yield of the common bean plant by increasing the number of flowers on the plant.
\end{abstract}

Key words: Compound inflorescence; Genetic components; Heritability; Phaseolus vulgaris; Plant breeding 


\section{INTRODUCTION}

The grain yield of a plant $(\mathrm{w})$ is dependent on the number of pods $(\mathrm{x})$, the number of seeds per pod (y), and mean weight of the grains $(\mathrm{z})$, and $\mathrm{w}=\mathrm{x} \cdot \mathrm{y} \cdot \mathrm{z}$. The contribution of each of these components to production is variable; however, in numerous situations, the number of pods per plant is the most important factor in production (Costa and Zimmermann, 1988; Zilio et al., 2011).

The number of pods is a function of the flowers produced per plant and the pod set from the floral stage. Various studies observed that pod set varies depending on the line and environment, and is normally low (Ramalho and Ferreira, 1979; Reis et al., 1985). The number of flowers produced per plant also varies depending on the line and the environment; the time of their appearance on the plant is also important. Distribution on the plant depends on the type of growth habit. The lines with determined growth habit begin flowering from top to bottom, whereas those with indeterminate growth habit flower in the opposite direction (Santos and Gavilanes, 2006).

For common bean, previous studies indicated that there are 2 types of inflorescence: isolated flowers or flowers in a cluster of 2-6 flowers (Santos and Gavilanes, 2006). In a collection of lines, some lines showed inflorescences that were completely different from those described in the literature and from those observed in Brazilian commercial cultivars. In this case, plants had few clusters; however, each inflorescence had a large number of flowers (Figure 1).

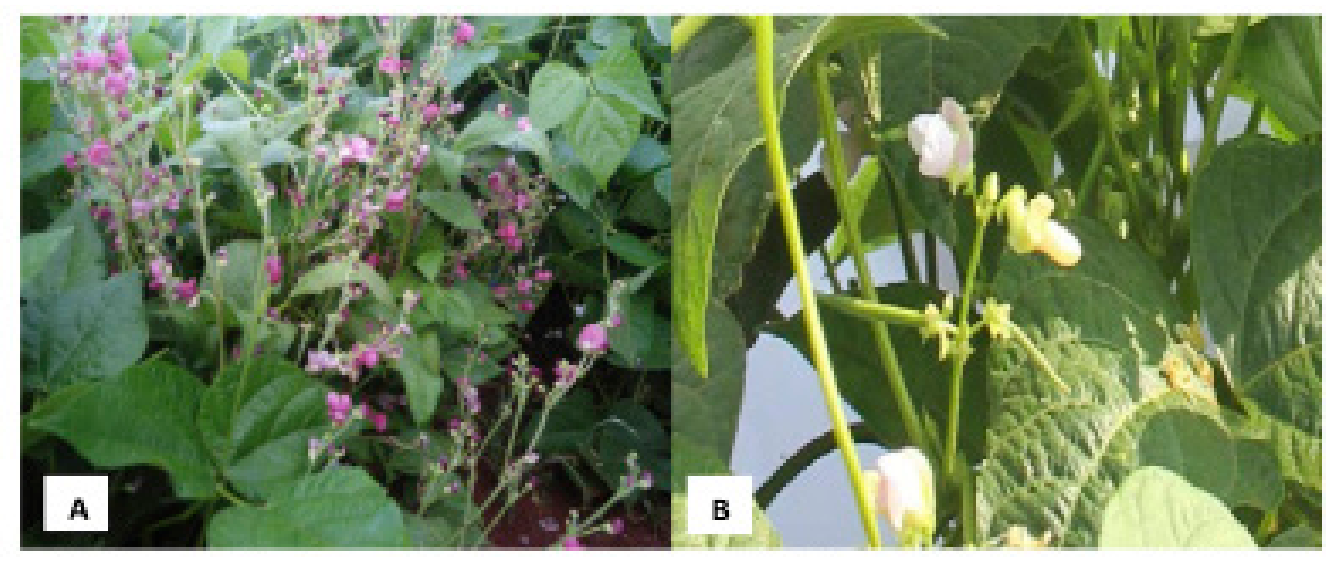

Figure 1. Types of inflorescences of the lines used in the crosses. Composite (A) and simple (B) inflorescences.

Few studies have examined the genetic control of inflorescence type in common bean and fewer have examined the implications of the number of flowers and of their distribution on the plant to increase grain yield potential. The present study was carried out to assess the genetic control of inflorescence in common bean in crosses of Brazilian lines with exotic lines that differ in the number and distribution of flowers, verifying the association between the number of flowers and their distribution on the plant with grain yield.

\section{MATERIAL AND METHODS}

Experiments were conducted in a greenhouse and in the experimental area of the Depart- 
ment of Biology of the Universidade Federal de Lavras (UFLA). The municipality of Lavras is located in the south of the state of Minas Gerais, Brazil, at $918 \mathrm{~m}$ in altitude $\left(21^{\circ} 58^{\prime} \mathrm{S}\right.$ and $\left.42^{\circ} 22^{\prime} \mathrm{W}\right)$.

The cultivar BRSMG Talismã (Talismã) was used as female parent, derived from a recurrent selection program carried out in the State of Minas Gerais. Two male parents were used, including the 59583 line (L.59583) which has compound inflorescences with insertion of multiple flowers of a dark-pink color, and the 59692 line (L.59692) which has compound inflorescences with insertion of multiple flowers of a light pink color; both lines were from the germplasm bank of the Embrapa Recursos Genéticos e Biotecnologia (CENARGEN) (Table 1).

Table 1. Origin and some characteristics of the genetic materials used in the crosses.
\begin{tabular}{llllc}
\hline Genetic material & Origin & Type of inflorescence & Grain color & 100 seed weight (g) \\
\hline BRSMG Talismã (P1) & UFLA/EMBRAPA/EPAMIG/UFV & Single & $\begin{array}{l}\text { Cream colored with } \\
\text { light-brown stripes }\end{array}$ & 26.5 \\
L.59583 (P2) & CENARGEN & Compound & Cream colored & 24.0 \\
L.59692 (P3) & CENARGEN & Compound & Cream colored & 22.7 \\
\hline
\end{tabular}

A preliminary study was carried out in a greenhouse using Talismã and L.59583 as parents to quantify the number of flowers and pods on each plant. Each flower was marked at the time of opening, and the number of flowers (NF) was counted as the quantity of tags and the number of pods on each plant $(\mathrm{X})$. Pod set from the floral stage $(\mathrm{V} \%)$ was determined using the expression $\mathrm{V} \%=[(\mathrm{X} / \mathrm{NF}) \times 100]$.

Two crosses were made; the first was Talismã x L.59583 and the second was Talismã x L.59692. The $\mathrm{F}_{1}$ generation was obtained in a greenhouse at the Departamento de Biologia at UFLA and the $\mathrm{F}_{2}$ and $\mathrm{F}_{3}$ generations were obtained in the field after being sown in February 2012 and in May of the same year. It was not possible to obtain the backcrosses because in the hybridizations in which the female parent was L.59583 or L.59692, the pod set in the hybrids was not present.

Each cross was subjected to analysis. A randomized block experimental design was used with 2 replications and 5 treatments, which included the parents and the $\mathrm{F}_{1}, \mathrm{~F}_{2}$, and $\mathrm{F}_{3}$ generations. The parent and the $\mathrm{F}_{1}$ plots were composed of 1 -m rows, with 1 row constituting a plot. The $\mathrm{F}_{2}$ and $\mathrm{F}_{3}$ plots consisted of $101-\mathrm{m}$ rows. Rows were spaced at $60 \mathrm{~cm}$ and 10 seeds/linear meter were used. Sowing was conducted in February 2013 and crop management practices were used as recommended for the crop in this region.

All data were collected from individual plants at the time of harvest. The following traits were assessed: length of the inflorescence (LI), measured using a ruler from the point of connection to the stem to the other extremity (and data from 1 inflorescence or, when present, 3 inflorescences per plant were obtained); number of pods per inflorescence (NPI); number of pods per plant $(\mathrm{X})$; number of grains per plant (NG); 100-grain weight (Z); and grain yield per plant (W).

The data were subjected to analysis of variance. To estimate the mean values and variances, the average genetic components and variance were obtained. An additive-dominance model without epistasis was considered. The weighted least squares method was used as described by Ramalho et al. (2012). By estimating the components of variance, estimates of heritability in the narrow sense $\left(h_{r}^{2}\right)$ were obtained according to the method described by Bernardo (2010).

The phenotypic and genetic correlations of all trait pairs were obtained using the procedure proposed by Falconer and Mackay (1996). 


\section{RESULTS}

The average number of flowers per plant (NF) obtained in a greenhouse was 70 for L.59583 and 11 for Talismã. The average number of pods per plant (X) was 16.3 for L.59583 and 7.5 for Talismã. Pod set from the floral stage was observed at $22 \%$ for L.59583 and $68 \%$ for Talismã. A difference was observed between the mean values of the parents for all traits.

In the estimates of the mean components for all traits assessed in the 2 crosses, the additive-dominance model without epistasis explained most of the variation; the $\mathrm{R}^{2}$ was greater than $98 \%$ (Tables 2-5). The component that estimates the deviation in homozygotes in relation to the mean value $(\alpha)$ and the contribution of the heterozygote $(\delta)$ in the 2 crosses was different from 0 in every case. Nevertheless, with the exception of inflorescence length, the estimate for $\alpha$ was of lower magnitude than that of $\delta$. The estimates of heterosis obtained varied among the traits; however, in general, they were of medium to large magnitude.

Table 2. Estimates of the mean values, variances (in brackets), and heterosis of the traits: length of the inflorescence (LI), number of pods per inflorescence (NPI), number of pods (X), number of grains (NG), 100 -grain weight (Z), and grain yield (W) obtained in the Talismã x L.59583 cross.

\begin{tabular}{lcccccc}
\hline & LI & NPI & X & NG & Z \\
\hline Talismã $\left(\mathrm{P}_{1}\right)$ & $2.85\left(0.29^{1}\right)$ & $1.8(0.15)$ & $21.5(7.46)$ & $101.4(81.5)$ & $21.5(6.9)$ & $21.8(12.7)$ \\
L.59583 $\left(\mathrm{P}_{2}\right)$ & $12.7(0.28)$ & $1.9(0.19)$ & $13.7(11.4)$ & $24.4(48.3)$ & $24.0(10.7)$ & $5.9(5.6)$ \\
$\mathrm{F}_{1}$ & $11.4(0.53)$ & $1.9(0.10)$ & $48.3(9.10)$ & $178.2(41.0)$ & $27.7(2.6)$ & $49.5(16.3)$ \\
$\mathrm{F}_{2}$ & $6.2(4.99)$ & $1.8(0.36)$ & $28.2(76.3)$ & $96.4(1419.0)$ & $23.5(14.9)$ & $22.3(76.7)$ \\
$\mathrm{F}_{3}$ & $5.3(4.70)$ & $1.6(0.37)$ & $25.3(73.8)$ & $92.1(1372.0)$ & $20.7(12.9)$ & $19.0(68.7)$ \\
Heterosis (\%) & 31.8 & 2.6 & 167.7 & 64.7 & 18.0 & 71.9 \\
\hline
\end{tabular}

${ }^{1}$ Associated standard errors.

Table 3. Estimates of the mean values, variances (in brackets), and heterosis of the traits: length of the inflorescence (LI), number of pods per inflorescence (NPI), number of pods (X), number of grains (NG), 100-grain weight (Z), and grain yield (W) obtained in the Talismã x L.59692 cross.

\begin{tabular}{|c|c|c|c|c|c|c|}
\hline & LI & NPI & $\mathrm{X}$ & NG & Z & GY \\
\hline Talismã $\left(\mathrm{P}_{1}\right)$ & $29.1\left(1.1^{1}\right)$ & $4.9(0.1)$ & $28.5(19.7)$ & $154.6(80.5)$ & $18.8(6.16)$ & $2.1(20.8)$ \\
\hline L. $59692\left(\mathrm{P}_{3}\right)$ & $34.5(0.5)$ & $13.3(0.2)$ & 31.9 (11.4) & $152.7(162.3)$ & $22.7(11.13)$ & $1.1(20.9)$ \\
\hline $\mathrm{F}_{1}$ & $42.3(2.8)$ & $10.6(0.3)$ & $38.5(22.8)$ & $176.3(73.8)$ & $24.1(7.85)$ & $1.6(22.6)$ \\
\hline $\mathrm{F}_{2}$ & $23.5(3.9)$ & $6.1(0.5)$ & $26.4(85.6)$ & $104.9(1369.0)$ & $22.7(35.7)$ & $1.8(90.4)$ \\
\hline & $22.9(4.8)$ & $5.5(0.4)$ & $26.4(89.5)$ & $104.3(1373.0)$ & $22.2(14.3)$ & $1.6(68.3)$ \\
\hline Heterosis $(\%)$ & 14.4 & 0.9 & 21.7 & 12.8 & 13.8 & 24.9 \\
\hline
\end{tabular}

${ }^{1}$ Associated standard errors.

Table 4. Estimates of the mean and variance components of the traits: length of inflorescence (LI), number of pods per inflorescence (NPI), number of pods (X), number of grains (NG), grain yield (W), and 100-grain weight (Z) of the Talismã x L.59583 cross.

\begin{tabular}{lcccccc}
\hline & LI & NPI & X & NG & W \\
\hline$\hat{m}$ & $19.8\left(0.39^{1,2}\right)$ & $16.94(0.60)$ & $60.9(1.66)$ & $11.9(0.57)$ & $6.84(0.11)$ & $1.67(0.06)$ \\
$\hat{a}$ & $0.16(0.66)$ & $4.25(0.71)$ & $38.6(1.81)$ & $7.7(0.67)$ & $4.66(0.12)$ & $0.07(0.09)$ \\
$\hat{d}$ & $7.46(0.73)$ & $29.56(1.17)$ & $114.4(2.69)$ & $31.4(1.33)$ & $2.76(0.25)$ & $0.17(0.13)$ \\
$\hat{V}^{e}$ & $3.57(1.07)$ & $8.47(2.22)$ & $50.30(13.5)$ & $8.47(2.42)$ & $0.32(0.08)$ & $0.12(0.03)$ \\
$\hat{V}_{A}^{A}$ & $5.23(1.60)$ & $38.7(28.32)$ & $783.6(152.8)$ & $34.56(7.82)$ & $2.57(0.53)$ & $0.15(0.04)$ \\
$\hat{V}_{D}$ & $6.18(2.90)$ & $29.13(15.1)$ & $585.08(280.3)$ & $33.68(14.89)$ & $2.10(0.97)$ & $0.09(0.09)$ \\
${ }^{3} \mathrm{R}^{2}$ & 99.79 & 99.59 & 99.65 & 97.87 & 96.18 & 99.74 \\
$h_{r}^{2}(\%)$ & 34.9 & 50.7 & 55.2 & 45.0 & 51.5 & 41.6 \\
\hline
\end{tabular}

${ }^{1}$ Associated standard errors; ${ }^{2}$ all the components were different than 0 at the level of $1 \%$ probability by the $t$-test; ${ }^{3}$ coefficient of determination of the model. 
Table 5. Estimates of the mean and variance components of the traits: length of inflorescence (LI), number of pods per inflorescence (NPI), number of pods (X), number of grains (NG), grain yield (W), and 100-grain weight (Z) of the Talismã x L.59692 cross.

\begin{tabular}{lcccrrr}
\hline & LI & NPI & X & NG & W & Z \\
\hline$\hat{m}$ & $7.65\left(0.18^{1,2}\right)$ & $1.59(0.06)$ & $16.94(0.60)$ & $130.19(2.34)$ & $24.33(0.81)$ & $7.2(0.58)$ \\
$\hat{a}$ & $4.41(0.21)$ & $0.48(0.09)$ & $4.25(0.71)$ & $13.12(2.65)$ & $-1.04(1.09)$ & $0.05(0.89)$ \\
$\hat{d}$ & $-2.09(0.48)$ & $0.16(0.17)$ & $29.56(1.17)$ & $29.18(4.01)$ & $8.06(1.87)$ & $28.56(1.46)$ \\
$\hat{V}^{e}$ & $0.75(0.24)$ & $0.11(0.03)$ & $15.56(4.5)$ & $83.93(24.13)$ & $21.36\left(5.9^{1}\right)$ & $7.21(2.05)$ \\
$\hat{V}_{A}$ & $2.55(0.56)$ & $0.11(0.05)$ & $45.14(10.7)$ & $774.24(159.5)$ & $23.71(8.9)$ & $0.05(2.29)$ \\
$\hat{V}_{D}$ & $0.68\left(0.92^{\text {ns }}\right)$ & $0.28(0.101)$ & $24.88(18.9)$ & $510.83(297.6)$ & $45.33\left(18.6^{\text {ns }}\right)$ & $28.6(6.89)$ \\
${ }^{3} \mathrm{R}^{2}$ & 96.18 & 99.74 & 99.59 & 99.65 & 97.87 & 99.79 \\
$h_{r}^{2}(\%)$ & 64.1 & 22.0 & 52.74 & 56.6 & 48.4 & 0.13 \\
\hline
\end{tabular}

${ }^{1}$ Associated errors; ${ }^{2}$ all the components were different than 0 at the level of $1 \%$ probability by the $t$-test; ${ }^{3}$ coefficient of determination of the model. ${ }^{\text {ns }}$ Not significant.

Estimates of phenotypic and genetic variance also varied among the traits and among the crosses (Tables 4 and 5). The additive variance $\left(\zeta_{A}\right)$ and dominance variance $\left(\varsigma_{A}\right)$ components were different than 0 for all traits in the 2 crosses carried out. The estimate for $\varsigma_{A}$ was greater than that of $\zeta_{\Delta}$. The estimates of heritabilities $\left(h^{2}\right)$ at the individual level were high for most traits in both crosses. For X, NG, and LI, high estimates were observed for the 2 crosses (greater than 50\%), with the cross using L.59692 showing that LI was 64.1\%, while for the traits of 100-grain weight and NPI in both crosses, the estimate was less than $45 \%$. For plant yield, in both crosses, the estimates of heritability were $45 \%$ for Talismã and $48.4 \%$ for L.59583 (Tables 4 and 5).

The magnitude and the sign for the estimates of genetic correlation were very similar to the estimates of phenotypic correlation (Tables 6 and 7). Particularly, the phenotypic and genetic correlations between the $2 \times 2$ traits were low in magnitude for the 2 crosses, except for NG and X with W. Associations between LI and any of the other traits assessed in the Talismã $x$ L.59583 cross were not detected. For the other cross, the estimates for LI with NPI, X, and $\mathrm{Z}$ were also low but significant $(\mathrm{P} \leq 0.01)$.

Table 6. Estimates of the genetic (above the diagonal) and phenotypic (below the diagonal) correlations between the traits length of inflorescence (LI), number of pods per inflorescence (NPI), number of pods (X), number of grains (NG), 100-grain weight (Z), and grain yield (W). Data obtained for the Talismã x L.59583 cross.

\begin{tabular}{|c|c|c|c|c|c|c|}
\hline & LI & NPI & $X$ & NG & Z & W \\
\hline LI & 1 & -0.19 & 0.02 & -0.11 & 0.05 & -0.06 \\
\hline NPI & -0.13 & 1 & 0.13 & 0.28 & -0.15 & 0.24 \\
\hline X & -0.03 & 0.11 & 1 & 0.55 & 0.20 & 0.60 \\
\hline NG & -0.14 & $0.26 * *$ & $0.62 * *$ & 1 & -0.15 & 0.85 \\
\hline Z & 0.11 & -0.02 & $0.21 * *$ & $-0.22 * *$ & 1 & 0.18 \\
\hline W & -0.11 & $0.23 * *$ & $0.71 * *$ & $0.92 * *$ & 0.15 & 1 \\
\hline
\end{tabular}

**Correlation estimate is different than 0 at the level of $1 \%$ probability by the $t$-test.

\section{DISCUSSION}

One of the difficulties in carrying out this study was the assessment of flowering. Counting the flowers of all plants in the experiment was not practical. Therefore, a prelimi- 
Table 7. Estimates of the genetic (above the diagonal) and phenotypic (below the diagonal) correlations between the traits length of inflorescence (LI), number of pods per inflorescence (NPI), number of pods (X), number of grains (NG), 100-grain weight (Z), and grain yield (W). Data obtained for the Talismã x L.59692 cross.

\begin{tabular}{lllccr}
\hline & LI & NPI & X & NG & Z \\
\hline LI & 1 & -0.85 & -0.44 & -0.27 & -0.26 \\
NPI & $-0.53^{* *}$ & 1 & -0.30 & -0.17 & -0.06 \\
X & $-0.28^{* *}$ & $-0.21^{* *}$ & 1 & -0.39 & -0.04 \\
NG & -0.19 & -0.13 & $0.76^{* *}$ & 1 & -0.07 \\
Z & $-0.29^{* *}$ & -0.05 & -0.03 & -0.14 & 0.79 \\
W & -0.02 & -0.05 & $0.70^{* *}$ & $0.80^{* *}$ & $-0.47 * *$ \\
\hline
\end{tabular}

**Correlation estimate is different than 0 at the.

nary study was carried out in a greenhouse with the parents Talismã and L.59583. The number of flowers per plant for L.59583 was 7-fold greater than for Talismã. Under field conditions, where plant development is higher, the number of flowers is expected to be greater, but the proportionality between the parents may be maintained. As the mean number of pods per plant in L.59583 was lower than in Talismã, the pod set from the floral stage for L.59583 was much lower. Previous reports regarding pod set in common bean were lower than $30 \%$, on average (Ramalho and Ferreira, 1979; Reis et al., 1985). In the present study, both in a greenhouse and under field conditions, pod set from the floral stage of L.59583 and L.59692 were low; this may be because these 2 lines are not adapted to the region. Thus, large number of flowers does not result in greater number of pods per plant.

In addition, flower distribution in the plants of the 2 parents differed. In L.59583, the flowers were concentrated in 1 or a few inflorescences, while in Talismã, there were few flowers per inflorescence, with innumerable inflorescences per plant. LI was used to assess the difference in flower distribution. Inflorescence was measured after harvest; if performed in the field at the time of flowering, it would be difficult to obtain information from the plant and the pod setting would be reduced. Because information regarding length was obtained after harvest, some flowers located at the extremities may not have set, and thus the measurement may have been underestimated. However, a significant difference was observed for this trait in the 2 parents involved in the 2 crosses.

For LI, the additive-dominance model explained most of the variation in both cases, with an $\mathrm{R}^{2}$ greater than $96 \%$. Additionally, $\alpha$, which was used to measure the deviation of the homozygote compared to the mean value, was greater than component $\delta$, which is the contribution of the heterozygote. Because in the 2-parent cross the allelic frequency is than half a, and the estimate of $\alpha$ was greater than that of $\delta$, the additive effects were stronger than the dominance effects in both crosses (Bernardo, 2010; Ramalho et al., 2012). This was confirmed based on the estimates of heterosis and of $V_{D}$ in relation to $V_{A}$, which were of small magnitude.

The estimate of heritability of LI was $57.8 \%$ for the crosses. In principle, this is a favorable condition for selection. However, the trait is difficult to measure, making it unviable for use in selecting plants with a greater number of flowers. Unfortunately, no studies have reported the genetic control of LI in the common bean. In cowpea (Vigna unguiculata L.), flowering shows differences from the common bean, but some plants show single and compound inflorescence, which is similar to our results. Among the traits assessed by Barros et al. (2011) in cowpea, the length of the peduncle with pods was estimated, which is a trait similar to LI. $\mathrm{F}_{3: 4}$ progenies from the cross between contrasting lines for the type of inflorescence were used. The $\mathrm{h}^{2}$ estimate based on the mean of the progenies was $83 \%$. Thus it cannot be directly 
comparable to the $\mathrm{h}^{2}$ estimate obtained in this study, which was at the individual level.

The mean components of NPI showed that $\alpha$ was similar to $\delta$ in the 'Talismã' $\mathrm{x}$ L. 59583 cross. In the other cross, $\alpha$ was greater than $\delta$. As already stated for LI, the additive effect was predominant for NPI. In a study examining the genetic control of some common bean inflorescence components, additive effects in the NPI were also observed (Diniz et al., 1989).

For $\mathrm{X}$, the distribution of frequency of the $\mathrm{F}_{2}$ generation revealed that the plants varied widely for this trait. In both crosses, the estimate of $\alpha$ was much less than that of $\delta$, particularly in the Talismã x L.59583 cross. These results indicate dominance in the expression of the number of pods per plant (Bernardo, 2010; Ramalho et al., 2012). Bernardo (2010) reported that the estimate of $\varsigma_{\Delta}$ should always be lower than $\varsigma_{A}$, unless the allele frequencies are extreme or over dominance exists.

The similarity between $\varsigma_{\Delta}$ and $\varsigma_{A}$ (Tables 4 and 5) demonstrated dominance in control of the trait. In the literature, some information is available regarding the genetic control of $\mathrm{X}$; however, different methods were used in the studies. Through diallel crosses, Sarafi (1978), Takeda et al. (1991), and Vizgarra (1991) demonstrated that $\varsigma_{A}$ was much higher than $\varsigma_{\Delta}$; similarly, Souza and Ramalho (1995) and Abreu (1989) demonstrated this using progenies. In contrast, Santos et al. (1985), Albuquerque and Vieira (1974), Hamblin and Morton (1977), and Foolad and Bassiri (1983), using diallel crosses, observed that $\varsigma_{\Delta}$ was greater than $\varsigma_{A}$, as observed in this study.

Estimates of $\mathrm{h}^{2}$ at the plant level, observed in this study as $\mathrm{X}$ (mean value of $51.72 \%$ ), were of medium to high magnitude (Takeda et al., 1991; Melo et al., 2004). However, the comparison of heritability estimates is typically hindered by differences in method and environmental conditions. Ramalho et al. (1979) assessed pure lines and observed estimates of heritability for X from 4-46\%. Takeda et al. (1991) used diallel crosses, Santos and Vencovsky (1986) used common bean progenies from different generations, and Melo et al. (2004) assessed pure lines, and all studies observed estimates of $23-60 \%$, with a mean value of $39.5 \%$.

According to Falconer and Mackay (1996), heterosis (h) is a function of the presence of dominance $(\delta)$, which differs from 0 based on the divergence between parents $(\mathrm{Y})$, i.e., $\mathrm{h}=$ $\mathrm{Y}^{2} \mathrm{x} d$. Because $d$ differed from 0 for $\mathrm{X}, \mathrm{NG}, \mathrm{Z}$, and $\mathrm{W}$ (Tables 4 and 5) and the parents were divergent, the estimate of heterosis in the Talismã x L.59583 cross was nearly always of large magnitude (Tables 2 and 3 ) and is the opposite of what is typically observed in the cross between 2 adapted lines (Baldoni et al., 2008).

In estimates of the mean components of $\mathrm{NG}$, the contribution of $\delta$ was higher than that of $\alpha$. Estimates for the genetic components of variance were similar. Previous studies examining the genetic control of grain number used parents and estimation method that was different from that used in this study, as already reported for X. Souza and Ramalho (1995), using $\mathrm{F}_{3: 4}$ and $F_{3: 5}$ progenies in the Jalo $x$ Small White cross, found that $\varsigma_{A}$ was much greater than $\varsigma_{\Delta}$. Sarafi (1978) and Santos et al. (1985) conducted diallel crosses and also obtained estimates of $\varsigma_{A}$ that were greater than estimates of $\varsigma_{A}$. In contrast, in this study, the allelic interaction of dominance was less important. Santos et al. (1986), Melo et al. (2002), Lana et al. (2003), and Silva et al. (2004) reported that the estimates of heritability at the mean level of progenies were of similar magnitude.

Estimates obtained for 100-grain weight $(Z)$ were very similar to those reported for X and NG. In contrast with the results of previous studies (Sarafi, 1978; Reis et al., 1981; Santos, 1984; Souza and Ramalho, 1995), the dominance effect was expressive.

In the final analysis, grain yield per plant was positively correlated with $\mathrm{X}$ and $\mathrm{NG}$ 
in both crosses. For the 100-grain weight $(Z)$, the correlation was negative in the Talismã $x$ L.59692 cross (Table 7). A positive association between X, NG, and Z was expected because grain yield is the product of these 3 components, i.e., $\mathrm{W}=\mathrm{X} \times \mathrm{NG} \times \mathrm{Z}$. The contribution of these components to grain yield, however, varies among plants of different lines and/or plants of a segregating population (Costa and Zimmermann, 1988; Zilio et al., 2011).

Because of the positive association between $\mathrm{X}$ and NG with $\mathrm{W}$, the inferences of genetic control of this trait were very similar to those reported for X and NG (Table 6 and 7), indicating a larger contribution of the allelic interaction of dominance to expression of the trait. Previous studies reported that in the genetic control of W, dominance was also important (Chung and Stevenson, 1973; Foolad and Bassiri, 1983). However, numerous other studies indicated the predominance of additive effects (Abreu, 1989; Takeda et al., 1991; Vizgarra, 1991; Moreto et al., 2007).

The discrepancy between the results of genetic control obtained in this study and previous studies regarding the importance of dominance for expression of traits $\mathrm{X}, \mathrm{NG}, \mathrm{Z}$, and $\mathrm{W}$ may be explained by considering that these traits must be controlled by various genes. Additionally, the type of allelic interaction of the different genes may be different. Moreover, the parents used in this study are quite different regarding adaptation. Talismã is a cultivar recommended for growth in the region because of its good yield and tolerance to some stresses, particularly biotic stress (Abreu et al., 2004), whereas the other 2 lines had not been grown in the region previously. L.59583 is a wild common bean and, therefore, quite divergent from Talismã.

Because the estimate of $\delta$ was expressive, wide segregation between the plants/progenies in segregating generations may have occurred. For $\delta$ to be different from zero, not only must the allelic interaction be dominant, but also parents should have contrasting loci for the trait. This would cause a large number of loci in heterozygosis, which in $\mathrm{F}_{1}$ is a condition for variability to be released in the segregating generations, as described by Ramalho et al. (2012).

The main focus of this study was to determine whether the larger number of flowers produced would be reflected in greater grain yield potential. However, this was not observed. The correlation between LI and grain yield was negative, although not significant. However, some plants in segregating generations exhibited a large number of pods, contributing to greater grain yield. The distribution of frequency of Win the $F_{2}$ generation reflected the wide variation observed. Success in terms of greater $\mathrm{W}$ not only results from an increase in number of flowers, but also from pod set from the floral stage. Thus, a trait that has not been greatly exploited in terms of breeding of the common bean and other legumes and which directly affects grain yield, is the grain-filling rate.

In a cross as divergent as Talismã x L.59583, it is also important to assess segregating populations with different proportions of the adapted parent, as was observed in the common bean (Baldoni et al., 2008) and soybean (Vello et al., 1984; Ininda et al., 1996). Thus, it will be possible to verify whether the reduction in participation of the non-adapted parent increases the probability of selecting plants/lines with a greater number of flowers and of pod set during the floral stage, thus increasing yield potential.

\section{CONCLUSIONS}

The traits associated with inflorescence in common bean (LI and NPI) exhibited genetic control with predominance of the alleles, showing an additive effect. Although moderate heritability was observed, these factors are difficult to measure, making selection of these 
traits difficult.

In the 2 crosses conducted in this study, genetic control of grain yield and of its primary components showed that the allelic interaction with dominance was expressive.

The association between LI and NPI with grain yield was low. However, the wide variability for the traits assessed leads to inference, making it possible to increase the yield potential of a common bean plant by increasing the number of flowers.

\section{REFERENCES}

Abreu A de FB (1989). Avaliação de Progênies de Feijoeiro do Cruzamento 'Carioca 80’ x 'Rio Tibagi' em Diferentes Densidades de Plantio. Master's thesis, Genética e Melhoramento de Plantas, Escola Superior de Agricultura de Lavras, Lavras.

Abreu A de FB, Ramalho MAP, Carneiro JE de S, Gonçalves FMA, et al. (2004). 'BRSMG Talismã': common bean cultivar with carioca grain type. Crop Breed. Appl. Biotechnol. 12: 372-374.

Albuquerque MM and Vieira C (1974). Manifestações da heterose em Phaseolus vulgaris L. Rev. Ceres 21: 148-166.

Baldoni AB, Ramalho MAP and Abreu A de FB (2008). Allele frequency and selection efficiency in cross populations of Andean x Mesoamerican common beans (Phaseolus vulgaris L. Fabales, Fabaceae). Genet. Mol. Biol. 31: 914-919.

Barros FR (2011). Potencial genético de progênies de feijão-caupi segregantes quanto ao tipo da inflorescência. Pesq. Agropec. Bras. 46: 182-189.

Bernardo R (2010). Breeding for Quantitative Traits in Plants. 2nd edn. Stemma, Woodbury.

Chung JH and Stevenson E (1973). Diallel analyses of the genetic variation in some quantitative characters in dry beans. New Zeal. J. Agr. Res. 16: 223-231.

Costa JCG and Zimmermann MJO (1988). Melhoramento Genético. In: A Cultura do Feijoeiro: Fatores que Afetam a Produtividade (Zimmermann MJO, Rocha M ana Yamada T, eds). Potafós, Piracicaba, 229-245.

Diniz A, Santos JB dos and Ramalho MAP (1989). Controle genético de alguns componentes da inflorescência do feijoeiro (Phaseolus vulgaris L.). Cienc. Cult. 7: 694-697.

Falconer DS and Mackay TFC (1996). Introduction to Quantitative Genetics. 4th edn. Longman Group Limited, Edinburgh.

Foolad MR and Bassiri A (1983). Estimates of combining ability, reciprocal effects and heterosis for yield and yield components in a common bean diallel cross. J. Agr. Sci. 100: 103-108.

Hamblin J and Morton JR (1977). Genetic interpretations of the effects of bulk breeding on four populations of beans (Phaseolus vulgaris L.). Euphytica 26: 75-83.

Ininda J, Fehr WR, Cianzio SR and Schnebly SR (1996). Genetic gain in soybean populations with different percentages of plant introduction parentage. Crop Sci. 36: 1470-1472.

Lana AMQ, Cardoso AA and Cruz CD (2003). Herdabilidades e correlações entre caracteres de linhagens de feijão obtidas em monocultivo e em consórcio com o milho. Ciência Rural 33: 1031-1037.

Melo LC, Santos JB and Ferreira DF (2002). Mapping and stability of QTLs for seed weight in common beans under different environments. Crop Breed. Appl. Biotechnol. 2: 227-236.

Melo LC, Santos JB and Ferreira DF (2004). QTL mapping for common bean grain yield in different environments. Crop Breed. Appl. Biotechnol. 4: 135-144.

Moreto AL, Antonio M, Ramalho P, Rodrigues Nunes JA, et al. (2007). Estimação dos componentes da variância fenotípica em feijoeiro utilizando método genealógico. Cienc. Agrotecnol. 31: 1035-1042.

Ramalho MAP and Ferreira MM (1979). Comportamento de cultivares de feijão (Phaseolus vulgaris L.) em relação ao florescimento e vingamento das vagens. Cienc. Pratica 3: 80-83.

Ramalho MAP, Andrade LAB and Teixeira NCS (1979). Correlações genéticas e fenotípicas entre caracteres do feijão (Phaseolus vulgaris L.). Cienc. Pratica 3: 63-70.

Ramalho MAP, Abreu A de FB, dos Santos JB and Rodrigues Nunes JA (2012). Aplicações da Genética Quantitativa no Melhoramento de Plantas Autógamas. Universidade Federal de Lavras, Lavras.

Reis WP, Ramalho MAP and Pinto CABP (1981). Herança do tamanho da semente do feijão (Phaseolus vulgaris L.). Cienc. Pratica 5: 66-71.

Reis WP, Ramalho MAP and Cruz JC (1985). Arranjos e populações do feijoeiro na consorciação com o milho. Pesq. Agropec. Bras. 20: 575-584.

Santos JB dos (1984). Controle Genético de Caracteres Agronômicos e Potencialidades de Cultivares de Feijão (Phaseolus vulgaris L.) para o Melhoramento Genético. Doctoral thesis, ESALQ, Piracicaba.

Santos J and Vencovsky R (1986). Correlação fenotípica e genética entre alguns caracteres agronômicos do feijoeiro 
(Phaseolus vulgaris L.). Cienc. Pratica 10: 265-272.

Santos JB and Gavilanes ML (2006). Botânica. In: Feijão (Vieira C, Paula Jr TJ, Borém A, eds.). Feijão. 2nd edn. Universidade Federal de Viçosa, 41-65.

Santos JB dos, Vencovsky R and Ramalho MAP (1985). Controle genético da produção de grãos e seus componentes primários em feijoeiro. Pesq. Agropec. Bras. 20: 1203-1211.

Santos PC dos, Cardoso AA, Vieira C and Silva JC (1986). Herdabilidades e correlações do rendimento com seus componentesem dois cruzamentos de feijão.

Sarafi A (1978). A yield-component selection experiment involving American and Iranian cultivars of the common bean. Crop Sci. 18: 5-7.

Silva NO, Ramalho MAP, Abreu A de FBA and Carneiro JES (2004). Performance of common bean families after different generations under natural selection. Genet. Mol. Biol. 27: 574-578.

Souza EA and Ramalho MAP (1995). Estimates of genetic and phenotypic variance of some traits of dry bean using a segregant population from the cross "Jalo" x "Small White". Rev. Bras. Genet. 18: 87-91.

Takeda C, Santos JB and Ramalho MAP (1991). Progeny test for the ESAL 501 x A354 common bean (Phaseolus vulgaris L.) hybrid at different locations. Rev. Bras. Genet. 14: 771-779.

Vello NA, Fehr WR and Bahrenfus JB (1984). Genetic variability and agronomic performance of soybean populations developed from plant introductions. Crop Sci. 24: 511-514.

Vizgarra ON (1991). Capacidade de Combinação de Algumas Cultivares de Feijoeiro com Diferentes Mecanismos de Resistência ao Vírus do Mosaico Dourado. Master's thesis, Escola Superior de Agricultura de Lavras, Lavras.

Zilio M, Coelho CMM, Souza CA, Santos JCP, et al. (2011). Contribuição dos componentes de rendimento na produtividade de genótipos crioulos de feijão (Phaseolus vulgaris L.). Rev. Cienc. Agronom. 42: 429-438. 